\title{
Identification of anti-repressor elements that confer high and stable protein production in mammalian cells
}

Ted HJ Kwaks, Phil Barnett, Wieger Hemrika, Tjalling Siersma, Richard GAB Sewalt, David PE Satijn, Janynke F Brons, Rik van Blokland, Paul Kwakman, Arle Kruckeberg, Angèle Kelder \& Arie P Otte

Nat. Biotechnol. 21, 553-558 (2003)

The accession numbers supplied by the authors in Table 1, p. 555, were incorrect. The correct ones are given below.

Old number Corrected number

$505648 \quad$ AY190749

$505650 \quad$ AY190750

$505652 \quad$ AY190751

$509911 \quad$ AY190752

$505656 \quad$ AY 190753

$505658 \quad$ AY 190754

$505660 \quad$ AY 190755

$505662 \quad$ AY190756

$509915 \quad$ AY 190757

505666 AY190758

\section{High-throughput engineering of the mouse genome coupled with high-} resolution expression analysis

David M Valenzuela, Andrew J Murphy, David Frendewey, Nicholas W Gale, Aris N Economides, Wojtek Auerbach, William T Poueymirou, Niels C Adams, Jose Rojas, Jason Yasenchak, Rostislav Chernomorski, Marylene Boucher, Andrea L Elsasser, Lakeisha Esau, Jenny Zheng, Jennifer Griffiths, Xiaorong Wang, Hong Su, Yingzi Xue, Melissa G Dominguez, Irene Noguera, Richard Torres, Lynn E Macdonald, A Francis Stewart, Thomas M DeChiara \& George D Yancopoulos Nat. Biotechnol. 21, 652-659 (2003)

In the author list, the name of author Rostislav Chernomorsky was misspelled Rostislav Chernomorski. In addition, an acknowledgment was omitted: the authors would like to acknowledge Panos Ioannou for help with early bacterial homologous recombination experiments. The corrected acknowlegments should read: We thank Margaret Karow for intellectual input, Petra Kraus for analysis of gene expression patterns and Fred W. Alt, Craig Bassing, Richard Flavell, Mike Brown, Joe Goldstein, Eric Shooter and Kornelia Polyak for suggesting genes to target. We thank Andrea Elsasser for excellent database design, implementation and support, and Dr. Amalia Dutra for advice and assistance with FISH. We would also like to thank Li Pan, Joyce McClain, Virginia Hughes, Jeffrey Vercollone, Kethi Mullei, Jorge Bermudez, Jennifer Leung, Ning Yuan, Samantha Park, Ruth Santos, Collen Correa, Huan Jiang, Jinsop Om and Youngli Chang for technical assistance, Vicki Lan and Scott Staton for graphics support and Panos Ioannou for help with early bacterial homologous recombination experiments. 